\title{
Analisis Soal Tes Pilihan Ganda Berbasis Higher Order Thinking Skill menggunakan Aplikasi Anates Windows Versi 4.0.9 For Windows
}

\author{
Ledi Merlin Purwati, Rizky Arianty, Diah Malaka Syakilah, Saiful Ridlo, Endang \\ Susilaningsih \\ Pascasarjana Universitas Negeri Semarang
}

\begin{abstract}
Abstrak
Indonesia dalam penilaian PISA termasuk dalam kategori rendah dalam kemampuan literasi. Hal ini diperlukannya berbagai upaya termasuk dalam evaluasi pembelajaran dengan menyediakan soal HOTS. Soal yang ideal akan melatih siswa untuk dapat berfikir kritis dalam pemecahan masalah. Penelitian ini bertujuan untuk menganalisis soal tes pilihan ganda berbasis HOTS menggunakan aplikasi Anates 4.0.9 for windows. Penelitian ini merupakan penelitian kuantitatif dengan metode deskriptif. Instrumen yang dibuat dalam penelitian ini ialah kisi-kisi soal dan butir soal HOTS. Penelitian ini melibatkan siswa kelas IV SDN 3 Kerandon Kabupaten Cirebon sejumlah 30 siswa. Hasil analisis menunjukkan mayoritas tingkat kesukaran soal kategori mudah, mayoritas daya pembeda soal kategori baik, efektivitas pengecoh kategori sangat baik, validitas soal sejumlah 16 dan soal yang diujikan bersifat reliabel. Hasil yang diperoleh kemudian dirangkum menjadi satu dalam rekap analisis butir soal.
\end{abstract}

Kata kunci: pilihan ganda; soal HOTS; aplikasi anates

\section{Pendahuluan}

PISA menentapkan subjek pengukuran membaca pada tahun 2000, 2009 dan 2018, matematika pada tahun 2003 dan 2012, serta sains pada tahun 2006 dan 2015 (OECD, 2019). PISA juga melakukan pengukuran kemampuan siswa di Indonesia pada ranah membaca, matematika, dan sains. Berdasarkan hasil penilaian PISA menyatakan bahwa Indonesia memiliki kemampuan membaca, matematika, dan 
sains yang rendah. Berikut ini gambar mengenai pengukuran PISA terhadap kemampuan literasi Indonesia

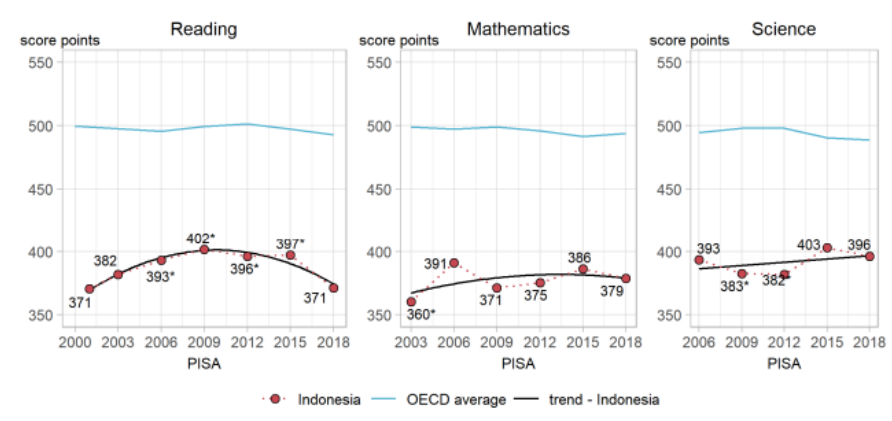

Gambar 1. Skor Indonesia di PISA 2018

Rendahnya tingkat penalaran siswa menjadikan rendahnya kemampuan berpikir yang dapat mempengaruhi kesulitan dalam menyelesaikan permasalahan. Sejalan dengan (Lestari, 2016) yang menyatakan bahwa siswa sekolah dasar masa kini dituntut untuk dapat menyelesaikan permasalahan yang dihadapinya melalui kegiatan menalar/berpikir.Piaget (dalam Kuswana, 2011), menyatakan bahwa anak telah memiliki ciri-ciri penggunaan logika yang memadai. Anak dituntut menjadi orang yang aktif untuk memperoleh pengetahuan. Keterampilan proses yang dimiliki siswa selama pembelajaran, menentukan hasil belajar yang diperoleh (Wicaksono, 2018).

Kemampuan bernalar yang baik pada siswa sekolah dasar dapat dilakukan dengan pengenalan latihan soal HOTS sebagai evaluasi dalam pembelajaran. Kemampuan berpikir kritis inilah yang diharapkan dapat membentuk diri siswa terampil dalam menyelesaikan permasalahan. Wilson (2000) Keterampilan berpikir merupakan gabungan dua kata yang memiliki makna berbeda, yaitu berpikir (thinking) dan keterampilan (skills). Hal ini sejalan dengan Gunawan (2003) bahwa Higher Order Thining Skill (HOTS) atau kemampuan berpikir tingkat tinggi merupakan proses berpikir yang mengharuskan mereka menemukan pengertian dan implikasi baru dengan memanipulasi informasi dan ide melalui cara tertentu. Misalnya seperti saat seseorang menerima informasi baru, dia akan mengaitkan dengan informasi yang telah diketahui sebelumnya sehingga membentuk informasi baru hasil dari penggabungan dua informasi yang didapat. Fanani (2018) berpikir tinggat tinggi dengan menerapkan soal HOTS sering diterjemahkan sebagai bagian dari taksonomi bloom yang terdiri atas analyze (C4), evaluate (C5), dan create (C6). Hal ini diperkuat oleh Kemendikbud (2017) memaparkan karakteristik soal-soal HOTS sebagai berikut : (1) mengukur kemampuan berpikir tingkat tinggi, (2) berbasis permasalahan kontekstual, (3) tidak rutin (tidak akrab), (4) menggunakan bentuk soal beragam. 
Dalam penerapannya, soal HOTS dapat disajikan dalam bentuk pilihan ganda. Arif (2014) soal pilihan ganda merupakan soal yang telah disediakan beberapa opsi jawaban. Sejalan dengan Depdiknas (2007) bentuk soal pilihan ganda terdiri dari dua bagian yaitu pokok soal (stem) yang berisi permasalahan yang akan ditanyakan dan sejumlah pilihan atau kemungkinan jawaban (option). Soal pilihan ganda sangat familiar dalam proses pembelajaran, soal tes ini merupakan soal tes obyektif yang banyak digunakan dalam melakukan evaluasi pembelajaran (Arta et al., 2020). Soal pilihan ganda (MCQ) biasanya digunakan banyak digunakan disekolah karena mudah dan akurat dinilai dan menghemat tenaga dan waktu yang signifikan (Jia et al., 2020). Tes pilihan ganda bersifat komprehensif, penilaian objektif dan pemeriksaan mudah, selain reliabilitas item yang tinggi, dapat mengukur berbagai tingkat kemampuan termasuk kemampuan berpikir tingkat tinggi (Rintayati et al., 2020). Bentuk soal pilihan ganda biasa, tiap alternatif jawaban berbentuk jawaban tunggal. Sedangkan pada bentuk soal pilihan kompleks, alternatif jawabannya dapat berupa gabungan jawaban betul (Hanifah, 2014). Penyusunanya soal pilihan ganda disajikan dalam bentuk pertanyaan yang dilengkapi dengan pilihan jawaban, siswa perlu memilih jawaban yang paling tepat diantara opsi yang disediakan. Jawaban benar hanyalah jawaban paling tepat, hal ini akan melatiha daya nalar dan berpikir kritis pada siswa. Kaidah penulisan soal bentuk pilihan ganda ada beberapa hal yang perlu diperhatikan, yaitu (1) materi, (2) konstruksi dan (3) bahasa (Arif, 2014).

Telaah terhadap hasil tes pilihan ganda dapat dilakukan dengan melibatkan teknologi modern. Anates merupakan program aplikasi yang dikembangkan oleh Drs. Karno To M.Pd., Dosen Psikologi di UPI dan Yudi Wibisono, S.T seorang Konsultan computer (Anggreini dan Darmawan, 2017). Anates mampu menghitung analisis butir soal secara cepat,mudah dan akurat, terlebih aplikasi ini berbahasa Indonesia (Arif, 2014). Sari dan Herawati (2014), anates memiliki kemampuan untuk menganalisa tes seperti: (1) Menghitung skor (asli maupun dibobot), (2) mengestimasi reliabilitas tes, (3) Mengelompokan subjek kedalam kelompok atas atau bawah, (4) Menghitung daya pembeda, (5) Menghitung tingkat kesukaran soal, (6) Menghitung korelasi skor butir dengan skor total, dan (7) Menentukan kualitas pengecoh (disktaktor). Kemampuan tersebut dilakukan secara sistematis, terukur, berkelanjutan serta menyeluruh pada setiap hasil butir soal yang di input (Reniasih, 2020).

Berdasarkan paparan di atas maka penelitian dilakukan dengan menganalisis butir soal pilihan ganda HOTS untuk melatih kemampuan literasi siswa. Pemanfaatan teknologi modern dalam perhitungan hasil kinerja siswa dalam menyelesaikan soal akan memperkecil kemungkinan kesalahan dalam menafsiran kemampuan siswa (Hidinia \& Suprijono, 2020). Penelitian ini melakukan analisis kualitas butir soal pilihan ganda berbasis HOTS dengan memanfaatkan aplikasi anates. Tujuan dari penelitian ini ialah untuk menganalisis butir soal HOTS jenis pilihan ganda yang ditinjau dari kualitas soal tes yang melalui tahap perhitungan hasil uji coba. 


\section{Metodologi}

Metode penelitian yang digunakan yaitu metode penelitian survey dengan pendekatan deskriptif kuantitatif. Peneilitian ini bertujuan untuk menggambarkan mengenai soal pilihan ganda berbasis HOTS, validitas, reliabilitas, daya beda, tingkat kesukaran. Penelitian ini dilaksanakan di Kabupaten Cirebon. Pengambilan data dalam peneliti ini dari siswa kelas IV SDN 3 Kerandon kecamatan Talun kabupaten Cirebon. Penelitian ini dilakukan pada tempat atau lokasi ini dipilih karena memiliki ciri-ciri yang bisa menggambarkan kondisi dan situasi yang sesuai dengan harapan penelitian. Subjek dalam penelitian ini adalah sumber data seluruh dokumen soal dan seluruh lembar jawaban penilaian evaluasi tema 9 (Kayanya Negeriku) Subtema 3 (Pelestarian Kekayaan Sumber Daya Alam di Indonesia). Penelitian dilakukan dengan melibatkan siswa kelas IV dengan jumlah soal 20 butir dalam bentuk pilihan ganda. Selain itu soal dibuat berdasarkan ketentuan dalam pembuatan soal HOTS di tingkat sekolah dasar.

Sampel penelitian menggunakan teknik purposive sampling. Perhitungan validitas, reliabilitas, daya pembeda dan tingkat kesukaran menggunakan bantuan program aplikasi Anates. Objek dalam penelitian ini adalah semua masalah yang nantinya akan dikaji, dibahas dan di teliti berdasarkan hasil analisis butir soal penilaian evaluasi kelas IV SDN 3 Kerandon dengan jumlah 30 siswa. Parameter penelitian yaitu analisis butir soal yaitu validitas butir soal, daya pembeda tiap butir soal, tingkat kesukaran, reliabilitas. Penelitian ini adalah penelitian kuantitatif dengan metode deskriptif. Penelitian ini menggunakan program Anates versi 4.0.9.

Analisis data dalam penelitian ini adalah analisis data kuantitatif berupa validitas, reliabilitas, daya pembeda, dan tingkat kesukaran. Penelitian terdiri atas dua tahap yaitu tahap persiapaan dengan menetapkan kisi-kisi soal yang akan dibuat dan membuat soal yang akan dianalisis. Prosedur penelitian pada tahap pelaksanaan terdiri dari membagikan soal kepada siswa melalui google form setelah soal diujikan kepada siswa kelas IV kemudian memeriksa hasil jawaban soal. Setelah mendapatkan skor siswa maka langkah selanjutnya adalah memasukkan hasil jawaban soal kedalam program komputer Anates versi 4.0.9 for Windows. Kegiatan analisis butir soal mengacu pada hasil penggunaan program komputer Anates versi 4.0.9 yaitu validitas butir soal, daya pembeda tiap butir soal, reliabilitas, tingkat kesukaran dan butir pengecoh. Hasil yang diperoleh dalam uji coba soal kemudian disajikan secara uraian deskriptif dengan mencantumkan hasil perhitungan dalam program komputer Anates versi 4.0.9 for Windows.

\section{$3 \quad$ Hasil dan Pembahasan}

Analisis butir soal sebelum dijadikan pedoman dalam penilaian evaluasi pembelajaran merupakan hal yang utama. Pasalnya, kegiatan analisis ini merupakan 
upaya untuk memaksimalkan mutu soal yang akan diberikan kepada siswa. Keberadaan soal yang bermutu ini diharapkan dapat menaungi berbagai tingkat kemampuan kompetensi siswa. Tujuan dari analisis ini untuk mengkaji dan menelaah setiap butir soal yang akan disajikan kepada peserta didik sebagai pedoman penilaian pembelajaran. Hasil penelitian ini mengungkapkan kualitas soal tes dengan paparan dari validitas butir soal, daya pembeda dan tingkat kesukaran soal.

\section{Tingkat Kesukaran Soal}

Tingkat kesukaran soal adalah persentase jumlah siswa yang menjawab soal dengan benar atau salah (Arikunto, 2010). Hal ini sejalan dengan Fatimah (2019) tingkat kesukaran soal adalah peluang untuk menjawab benar suatu soal pada suatu tingkat kemampuan atau bisa dikatakan untuk mengetahui sebuah soal itu tergolong mudah atau sukar. Tingkat kesukaran soal biasanya dinyatakan dalam bentuk indeks. Indeks tingkat kesukaran ini pada umumnya dinyatakan dalam bentuk proporsi yang besarnya berkisar 0,00 - 1,00. Kriteria tingkat kesukaran dapat dijelaskan pada tabel 1.

Tabel 1. Kriteria Tingkat Kesukaran

\begin{tabular}{cc}
\hline Interval & Kriteria \\
\hline $0,00<\mathrm{P} \leq 0,30$ & Butir soal susah \\
\hline $0,30<\mathrm{P} \leq 0,70$ & Butir soal sedang \\
\hline $0,70<\mathrm{P} \leq 1,00$ & Butir soal mudah \\
\hline
\end{tabular}

Tingkat kesukaran yang diperoleh dari hasil pengujian soal dapat dilihat pada gambar 2. 


$\begin{array}{rrrl}\text { No Butir Asli Jml Betul Tkt. Kesukaran(8) } & \text { Tafsiran } \\ 1 & 23 & 76,67 & \text { Mudah } \\ 2 & 19 & 63,33 & \text { Sedang } \\ 3 & 17 & 56,67 & \text { Sedang } \\ 4 & 20 & 66,67 & \text { Sedang } \\ 5 & 17 & 56,67 & \text { Sedang } \\ 6 & 14 & 46,67 & \text { Sedang } \\ 7 & 15 & 50,00 & \text { Sedang } \\ 8 & 15 & 50,00 & \text { Sedang } \\ 9 & 18 & 60,00 & \text { Sedang } \\ 10 & 19 & 63,33 & \text { Sedang } \\ 11 & 21 & 70,00 & \text { Sedang } \\ 12 & 20 & 66,67 & \text { Sedang } \\ 13 & 20 & 66,67 & \text { Sedang } \\ 14 & 20 & 66,67 & \text { Sedang } \\ 15 & 22 & 73,33 & \text { Mudah } \\ 16 & 12 & 40,00 & \text { Sedang } \\ 17 & 13 & 43,33 & \text { Sedang } \\ 18 & 17 & 56,67 & \text { Sedang } \\ 19 & 18 & 60,00 & \text { Sedang } \\ 20 & 23 & 76,67 & \text { Mudah }\end{array}$

Gambar 2. Tingkat Kesukaran Soal

Hasil analisis butir soal penilaian evaluasi tema 9 (Kayanya Negeriku) Subtema 3 (Pelastarian Kekayaan Sumber Daya Alam di Indonesia) Pembelajaran ke tiga dengan muatan pembelajaran Bahasa Indonesia dan IPA kelas IV adalah ada 3 butir soal yang memiliki kreteria mudah 17 soal memiliki kriteria sedang, 0 butir soal yang memiliki kreteria susah. Jika dilihat dari hasil analisis butir soal yang memiliki kreteria sedang adalah butir soal yang tidak terlalu mudah dan tidak terlalu sulit sehingga siswa akan terangsang untuk bisa memecahkan butir soal tersebut.

\section{Daya Pembeda}

Dalam bentuk soal pilihan ganda diperlukan adanya daya pembeda yang tercantum pada opsi jawaban. Daya pembeda ialah kemampuan suatu instrumen soal untuk mengklasifikasikan siswa berdasarkan tingkat kemampuannya (Arikunto, 2010). Hal ini sejalan dengan pendapat dari Naga (2002) bahwasannya daya pembeda soal adalah kemampuan dalam memisahkan dan membedakan peserta tes antara kelompok tinggi dan kelompok rendah. Untuk mengetahui kemampuan butir soal membedakan hasil tes dengan hasil jawaban yang benar dan hasil tes dengan hasil jawaban yang salah adalah fungsi dari daya pembeda. Penelitian ini kriteria yang digunakan dapat dilihat pada tabel 2.

Tabel 2. Kriteria Daya Beda Soal

\begin{tabular}{cc}
\hline Interval & Kriteria \\
\hline $\mathrm{DP} \leq 0,00$ & Sangat Jelek \\
\hline $0,00<\mathrm{DP} \leq 0,20$ & Jelek \\
\hline $0,20<\mathrm{DP} \leq 0,40$ & Cukup Baik \\
\hline
\end{tabular}




\begin{tabular}{cc}
\hline $0,40<\mathrm{DP} \leq 0,70$ & Baik \\
\hline $0,70<\mathrm{DP} \leq 1,00$ & Sangat Baik \\
\hline
\end{tabular}

Daya pembeda soal yang dianalisis menggunakan program komputer Anates versi 4.0.9 for Windows digambarkan pada gambar 3 .

$\begin{array}{rrrrr}\text { No Butir Asli } & \text { Kel. Atas } & \text { Kel. Bawah } & \text { Beda } & \text { Indeks DP (8) } \\ 1 & 8 & 2 & 6 & 75,00 \\ 2 & 8 & 1 & 7 & 87,50 \\ 3 & 7 & 2 & 5 & 62,50 \\ 4 & 8 & 2 & 6 & 75,00 \\ 5 & 7 & 3 & 4 & 50,00 \\ 6 & 6 & 1 & 5 & 62,50 \\ 7 & 6 & 3 & 3 & 37,50 \\ 8 & 6 & 3 & 3 & 37,50 \\ 9 & 7 & 3 & 4 & 50,00 \\ 10 & 7 & 4 & 3 & 37,50 \\ 11 & 8 & 2 & 6 & 75,00 \\ 12 & 8 & 2 & 6 & 75,00 \\ 13 & 8 & 2 & 6 & 75,00 \\ 14 & 8 & 1 & 7 & 87,50 \\ 15 & 8 & 2 & 6 & 75,00 \\ 16 & 6 & 0 & 6 & 75,00 \\ 17 & 6 & 1 & 5 & 62,50 \\ 18 & 6 & 2 & 4 & 50,00 \\ 19 & 7 & 2 & 5 & 62,50 \\ 20 & 8 & 3 & 5 & 62,50\end{array}$

Gambar 3. Daya Pembeda

Berdasarkan gambar diatas diperoleh daya pembeda dapat dikategorikan terdapat 9 butir soal dengan kriteria sangat baik yaitu nomor 1, 2, 4, 11, 12, 13, 14, 15, dan 16 . Soal dengan kriteria baik terdapat 11 soal dengan nomor 3, 5, 6, 7, 8, 9, 10, 17, 18, 19, dan 20. Soal dengan kriteria cukup baik, kriteria jelek dan sangat jelek terdapat 0 soal.

\section{Efektivitas Pengecoh}

Pengecoh atau distraktor adalah jawaban pengecoh yang memiliki perbedaan tipis dengan jawaban benar, sehingga sering menjebak siswa dalam menjawab soal tes yang diujikan (Setiawaty, 2017). Sejalan dengan Putri, dkk (2020) distraktor berfungsi mengecoh peserta tes untuk memilih jawaban yang benar. Soal pilihan ganda terdapat alternatif jawaban yang berfungsi untuk mengecoh jawaban yang benar. Terdapat tiga jawaban pengecoh yang terpasang pada setiap butir jawaban soal. Berdasarkan hasil soal penilaian evaluasi tema 9 (Kayanya Negeriku) Subtema 3 (Pelastarian Kekayaan Sumber Daya Alam di Indonesia) Pembelajaran ke tiga dengan muatan pembelajaran Bahasa Indonesia dan IPA kelas IV disimpulkan 
bahwa soal evaluasi memiliki efektifitas pengecoh dengan kriteria sangat baik, baik, buruk dan sangat buruk.

Analisis efektifitas pengecoh butir soal pilihan ganda dilihat dari hasil penyebaran jawaban siswa di setiap butir soal. Sebuah pengecoh dapat dikatakan baik jika setidaknya $5 \%$ dari peserta tes memilih opsi tersebut. Berikut adalah hasil analisis penyebaran jawaban siswa di setiap butir soal, dapat dilihat pada gambar 4 .

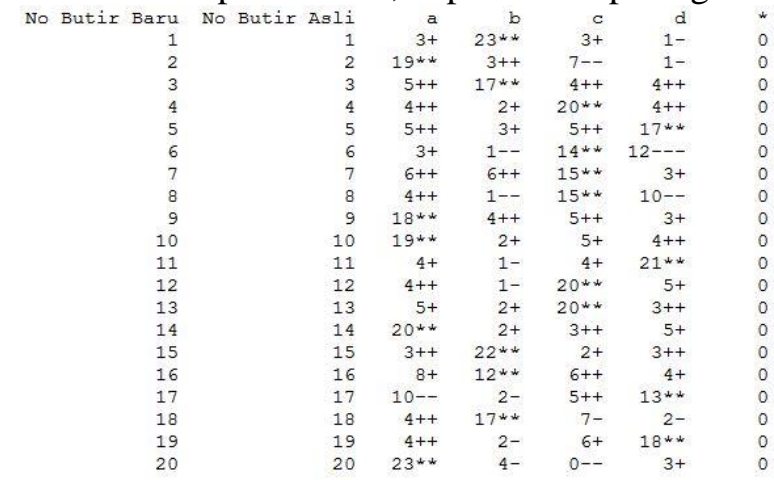

Gambar 4. Efektifitas Pengecoh

Simpulan efektivitas pengecoh pada setiap butir soal, peneliti menggunakan kriteria yang diadaptasi dari Skala Likert. Soal dikatakan memiliki efektivitas pengecoh yang sangat baik jika terdapat tiga jawaban pengecoh, soal memiliki efektivitas pengecoh yang baik jika terdapat dua jawaban pengecoh, soal dikatakan memiliki efektivitas pengecoh yang cukup baik jika terdapat satu jawaban pengecoh dan jika semua jawaban pengecoh tidak berfungsi maka soal dikatakan memiliki efektivitas pengecoh yang tidak baik.

Butir soal penilaian evaluasi tema 9 (Kayanya Negeriku) Subtema 3 (Pelastarian Kekayaan Sumber Daya Alam di Indonesia) Pembelajaran ke tiga dengan muatan pembelajaran Bahasa Indonesia dan IPA kelas IV terdapat efektitas pengecoh yang berfungsi dengan sangat baik yaitu terdapat pada nomor 3, 4, 5, 7, 9, 10, 13, 14, 15, dan 16. Pengecoh yang berfungsi dengan baik yaitu terdapat pada nomor $1,11,12$, dan 19. Pengecoh yang berfungsi dengan cukup baik yaitu terdapat pada nomor 2, 5, 8, 17, 18, dan 20. Dari penyebaran jawaban menggunakan anates versi 4.0.9 diperoleh hasil efektifitas pengecoh pada setiap butir soalnya pada tabel 3 .

Tabel 3. Efektifitas Pengecoh 


\begin{tabular}{|c|c|c|c|c|c|}
\multirow{2}{*}{ Nomor Soal } & \multicolumn{5}{|c|}{ Kualiatas Pengecoh } \\
\cline { 2 - 6 } & a & b & c & d & Tidak Menjawab \\
\hline 1 & Baik & Jawaban & Baik & Kurang & 0 \\
\hline 2 & Jawaban & Sangat baik & Buruk & Kurang & 0 \\
\hline 3 & Sangat Baik & Jawaban & Sangat Baik & Sangat Baik & 0 \\
\hline 4 & Sangat Baik & Baik & Jawaban & Sangat Baik & 0 \\
\hline 5 & Sangat Baik & Baik & Sangat Baik & Jawaban & 0 \\
\hline 6 & Baik & Buruk & Jawaban & Sangat Buruk & 0 \\
\hline 7 & Sangat Baik & Sangat baik & Jawaban & Baik & 0 \\
\hline 8 & Sangat Baik & Buruk & Jawaban & Buruk & 0 \\
\hline 9 & Jawaban & Sangat baik & Sangat Baik & Baik & 0 \\
\hline 10 & Jawaban & Baik & Baik & Sangat Baik & 0 \\
\hline 11 & Baik & Kurang & Baik & Jawaban & 0 \\
\hline 12 & Sangat Baik & Buruk & Jawaban & Baik & 0 \\
\hline 13 & Baik & Baik & Jawaban & Sangat Baik & 0 \\
\hline 14 & Jawaban & Baik & Sangat Baik & Baik & 0 \\
\hline 15 & Sangat Baik & Jawaban & Baik & Sangat Baik & 0 \\
\hline 16 & Baik & Jawaban & Sangat Baik & Baik & 0 \\
\hline 17 & Buruk & Kurang & Sangat Baik & Jawaban & 0 \\
\hline 18 & Sangat Baik & Jawaban & Kurang & Kurang & 0 \\
\hline 19 & Sangat Baik & Kurang & Baik & Jawaban & 0 \\
\hline 20 & Jawaban & Kurang & Buruk & Baik & 0 \\
\hline
\end{tabular}

\section{Validitas}

Analisis kelayakan soal dapat diukur melalui validitas. Ayunita (2018) menyatakan bahwa validitas kecermataan suatu insturmen dalam pengukuran. Sejalan dengan Sugiyono (2007) yang menyatakan bahwa validitas memiliki tujuan untuk mengukur isi instumen sehingga dapat diperoleh hasil layak atau tidak layak instrumen yang akan digunakan. Validitas butir soal yang dianalisis menggunakan program komputer Anates versi 4.0.9 for Windows digambarkan pada gambar 5.

$\begin{array}{rrl}\text { No Butir Asli } & \text { Korelasi } & \text { Signifikansi } \\ 1 & 0,661 & \text { Sangat Signifikan } \\ 2 & 0,667 & \text { Sangat Signifikan } \\ 3 & 0,532 & \text { Signifikan } \\ 4 & 0,555 & \text { Sangat Signifikan } \\ 5 & 0,413 & \text { - } \\ 6 & 0,585 & \text { Sangat Signifikan } \\ 7 & 0,478 & \text { Signifikan } \\ 8 & 0,478 & \text { Signifikan } \\ 9 & 0,510 & \text { Signifikan } \\ 10 & 0,409 & \text { - } \\ 11 & 0,470 & \text { Signifikan } \\ 12 & 0,611 & \text { Sangat Signifikan } \\ 13 & 0,611 & \text { Sangat Signifikan } \\ 14 & 0,708 & \text { Sangat Signifikan } \\ 15 & 0,678 & \text { Sangat Signifikan } \\ 16 & 0,518 & \text { Signifikan } \\ 17 & 0,471 & \text { Signifikan } \\ 18 & 0,400 & \text { - } \\ 19 & 0,417 & \text { - } \\ 20 & 0,552 \text { Sangat Signifikan }\end{array}$

Gambar 5. Validitas 
Hasil olahan Anates versi 4.0.9 for Windows dengan keterangan soal valid berjumlah 16 soal dan 4 soal tidak valid. Valid atau tidak validnya suatu item soal, dapat digunakan dengan teknik korelasi sebagai teknik analisisnya. Butir soal yang valid, dapat digunakan untuk tes hasil belajar, sedangkan butir soal yang tidak valid maka soal tidak bisa digunakan atau dibuang. Butir soal penilaian evaluasi tema 9 (Kayanya Negeriku) Subtema 3 (Pelastarian Kekayaan Sumber Daya Alam di Indonesia) Pembelajaran ke tiga dengan muatan pembelajaran Bahasa Indonesia dan IPA kelas IV yang dianalisis menggunakan program aplikasi anates dihasilkan butir soal dengan kreteria sangat signifikan berjumlah 9 butir yaitu butir soal dengan nomor $1,2,4,6,12,13,14,15$, dan 20 . Butir soal dengan kreteria yang signifikan berjumlah 7 soal dengan nomor $3,7,8,9,11,16$ dan 17 . Soal yang tidak signifikan berjumlah 4 butir soal dengan nomor 5, 10, 18, dan 19 .

Salah satu soal yang valid pada nomor 4 yaitu Pembuangan limbah pabrik kesungai dapat mengakibatkan pencemaran air sungai. Berikut bunyi soal "Di bawah ini merupakan pertanyaan yang dapat ditanyakan berkaitan dengan topik di atas, kecuali..."

a. Apa saja dampak buruk dari limbah pabrik bagi air sungai?

b. Bagaimana cara menanggulangi dampak buruk dari limbah pabrik yang dibuang ke sungai?

c. Mengapa sungai menjadi tempat yang cocok bagi pembuangan limbah pabrik?

d. Sejak kapan sungai menjadi tercemar akibat limbah pabrik?

Soal di atas merupakan salah satu soal yang valid, hal ini dapat dilihat dari korelasi yang diperoleh yaitu 0,555 . Korelasi ini merupakan koefesien yang sangat tinggi. Soal yang tidak valid pada nomor 10, dengan bunyi soal "Berikut ini pertanyaan yang sesuai mengenai topik Hemat Energi, kecuali..."

a. Kapan energi alternatif akan habis?

b. Apa yang dapat dilakukan sebagi upaya dalam melakukan hemat energi?

c. Siapa saja yang berperan dalam upaya hemat energi?

d. Bagaimana peran energi alternatif dalam upaya hemat energi?

Soal di atas merupakan salah satu soal yang tidak valid. Tidak validnya soal terjadi nilai korelasinya 0,409 . Korelasi yang diperoleh soal ini adalah korelasi lebih kecil dari $r$ tabel, dengan $t$ hitung kecil dari $r$ tabel maka soal tersebut tidak bisa digunakan dan tidak valid. karena koofesien korelasi dari analisis validitasnya pada taraf signifikansi $5 \%=0,468$. Korelasi pada taraf 5\% didapat butir soal yang valid berjumlah 16 soal, sedangkaan soal yang tidak valid berjumlah 4 soal.

\section{Reliabilitas}

Perhitungan estimasi reliabilitas dilakukan dalam analisis soal. Hal ini dikarenakan reliabilitas digunakan untuk mengetahui konsistensi alat ukur, untuk mendapatkan 
keputusan layak digunakan atau harus diulang (Ayunita, 2018). Sejalan dengan Malik and Chusni (2018) menyatakan bahwa reliabilitas merupakan ketepatan atau konsistensi suatu instrumen.

Dari 20 butir soal penilaian evaluasi tema 9 (Kayanya Negeriku) Subtema 3 (Pelastarian Kekayaan Sumber Daya Alam di Indonesia) Pembelajaran ke tiga dengan muatan pembelajaran Bahasa Indonesia dan IPA kelas IV yang dianalisis menggunakan program aplikasi anates dihasilkan indeks reliabilitas sebesar 0,96 dengan menggunakan teknik belah yaitu ganjil dan genap. Hasil reliabilitas tersebut masuk dalam kelompok kategori sangat tinggi dengan rentang 0,800-1,000 yang menunjukkan tingkat reliabilitas dengan kreteria sangat baik. Hasil koefisien reliabiltas dapat dilihat pada gambar 6.

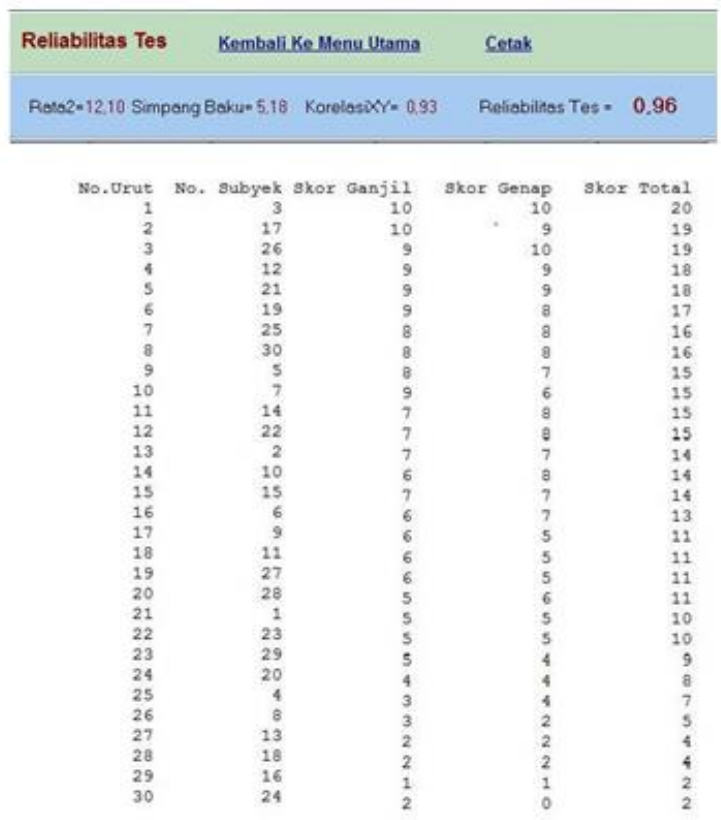

Gambar 6. Reliabilitas

\section{Rekap Analisis Butir Soal}

Kegiatan analisis yang telah dilaksanakan diatas merupakan analisis secara parsial yaitu analisis validitas, daya pembeda dan tingkat kesukaran. Analisis yang terakhir adalah analisis rekap secara keseluruhan, sehingga butir soal yang akan digunakan untuk selanjutnya bisa terlihat. Rekapitulasi hasil analisis butir soal dapat dilihat pada gambar 7 . 
Vol. 15; No. 02; 2021; 460-473

$\begin{array}{rrlrl}\text { Btr Asli } & \text { D.Pembeda(8) } & \text { T. Kesukaran } & \text { Korelasi } & \text { Sign. Korelasi } \\ 1 & 75,00 & \text { Mudah } & 0,661 & \text { Sangat Signifikan } \\ 2 & 87,50 & \text { Sedang } & 0,667 & \text { Sangat Signifikan } \\ 3 & 62,50 & \text { Sedang } & 0,532 & \text { Signifikan } \\ 4 & 75,00 & \text { Sedang } & 0,555 & \text { Sangat Signifikan } \\ 5 & 50,00 & \text { Sedang } & 0,413 & - \\ 6 & 62,50 & \text { Sedang } & 0,585 & \text { Sangat Signifikan } \\ 7 & 37,50 & \text { Sedang } & 0,478 & \text { Signifikan } \\ 8 & 37,50 & \text { Sedang } & 0,478 & \text { Signifikan } \\ 9 & 50,00 & \text { Sedang } & 0,510 & \text { Signifikan } \\ 10 & 37,50 & \text { Sedang } & 0,409 & \text { - } \\ 11 & 75,00 & \text { Sedang } & 0,470 & \text { Signifikan } \\ 12 & 75,00 & \text { Sedang } & 0,611 & \text { Sangat Signifikan } \\ 13 & 75,00 & \text { Sedang } & 0,611 & \text { Sangat Signifikan } \\ 14 & 87,50 & \text { Sedang } & 0,708 & \text { Sangat Signifikan } \\ 15 & 75,00 & \text { Mudah } & 0,678 & \text { Sangat Signifikan } \\ 16 & 75,00 & \text { Sedang } & 0,518 & \text { Signifikan } \\ 17 & 62,50 & \text { Sedang } & 0,471 & \text { Signifikan } \\ 18 & 50,00 & \text { Sedang } & 0,400 & - \\ 19 & 62,50 & \text { Sedang } & 0,417 & - \\ 20 & 62,50 & \text { Mudah } & 0,552 & \text { Sangat Signifikan }\end{array}$

\section{Gambar 7. Rekap Analisis Butir Soal}

Rata-Rata $=12,10$,Simpang Baku $=5,18$, Korelasi XY=0,93 dari 20 butir soal yang dianalisis menggunakan program aplikasi anates dihasilkan indeks reliabilitas sebesar 0,96 dengan menggunakan teknik belah yaitu ganjil dan genap. Setiap butirbutir soal yang berdasarkan hasil analisis dalam kategori valid berjumlah 16 butir soal maka butir soal tersebut sesuai dan butir soal tersebut dapat dikeluarkan lagi dalam tes hasil belajar pada waktu yang akan datang. Butir soal yang termasuk dalam kategori soal tidak valid diperbaiki dengan adanya tindak lanjut yaitu 4 butir soal, butir soal tersebut langsung di buang dan tidak dipakai lagi dalam tes selanjutnya dimasa yang akan datang, diteliti ulang, dan diperbaiki tata bahasanya sehingga apakah kalimat soal yang kurang jelas, soal sulit dipahami, dalam soal terdapat istilah yang tidak jelas. Setelah diperbaiki butir soal tersebut bisa digunakan kembali pada tes dimasa akan datang.

\section{Kesimpulan}

Berdasarkan hasil penelitian yang telah dilakukan bahwa analisis butir soal HOTS melalui penggunaan program komputer Anates versi 4.0.9 for Windows didapatkan validasi butir soal pada taraf signifikansi $5 \%$ didapat butir soal yang mayoritas tingkat kesukaran kategori sedang, mayoritas daya pembeda soal kategori baik, mayoritas efektivitas pengecoh kategori sangat baik, validitas soal berjumlah 16 dan uji coba soal bernilai reliabel sebesar 0,96 .

Hasil analisis rekap butir soal yang bisa digunakan berjumlah 16 butir soal, soal tersebut dapat dikeluarkan lagi dalam tes hasil belajar pada waktu yang akan datang, 4 butir soal yang termasuk dalam kategori soal tidak valid diperbaiki dengan adanya tindak lanjut yaitu butir soal tersebut langsung di buang dan tidak dipakai lagi dalam 
tes selanjutnya dimasa yang akan datang, atau diperbaiki, diteliti ulang, dan diperbaiki tata bahasanya.

\section{Daftar Pustaka}

Anggreini, D., \& Darmawan, C. A. (2017). Analisis Kualitas Soal Try Out Ujian Nasional Dengan Menggunakan Aplikasi Program Anates. JP2M (Jurnal Pendidikan Dan Pembelajaran Matematika), 2(1), 20. https://doi.org/10.29100/jp2m.v2i1.213

Arif, M. (2014). Penerapan aplikasi anates bentuk soal pilihan ganda. Jurnal Ilmiah Edutic, 1, 1-9.

Arikunto, S. (2010). Dasar-dasar Evaluasi Pendidikan. Jakarta: Bumi Aksara. 2010. Manajemen Penelitian.

Arta, K. S., Purnawati, D. M. O., \& ... (2020). Pelatihan Dan Pendampingan Pengembangan Dan Implementasi Asesmen Otentik Pada Guru-Guru Sd Di Kecamatan Seririt Kabupaten .... ... Media Ganesha FHIS, 1, 23-32. https://ejournal2.undiksha.ac.id/index.php/p2mfhis/article/view/301

Ayunita, D. (2018). Modul Uji Validitas dan Reliabilitas. Jurnal Tarbiyah: Jurnal Ilmiah Kependidikan, 7(1), 17-23.

Depdiknas. (2007). Panduan Penulisan Soal Pilihan Ganda. Jakarta: Pusat Penilaian Pendidikan Balitbang-Depdiknas.

Fanani, M. Z. (2018). Strategi Pengembangan Soal Hots Pada Kurikulum 2013. Edudeena, 2(1), 57-76. https://doi.org/10.30762/ed.v2i1.582

Fatimah, L. and A. K. (2019). Analisis Kesukaran Soal, Daya Pembeda dan Fungsi Distraktor. Jurnal Komunikasi Dan Pendidikan Islam, 8, 37-64.

Gunawan, A. W. (2003). Genius Learning Strategy: Petunjuk Praktis untuk Menerapkan Accelerated Learning. Jakarta: Gramedia Pustaka Utama.

Hanifah, N. (2014). Perbandingan Tingkat Kesukaran, Daya Pembeda Butir Soal Pilihan Ganda Asosiasi Mata Pelajaran Ekonomi. SOSIO E-KONS, 6(1), 4155.

Hidinia, D. P., \& Suprijono, A. (2020). Analisa Tingkat Kesulitan Soal Latihan Usbn 2019 Melalui Aplikasi Anates. Avatara, e-Journal Pendidikan Sejarah, $8(1), 1-5$.

Jia, B., He, D., \& Zhu, Z. (2020). Quality and Feature of Multiple-Choice Questions in Education. Problems of Education in the 21st Century, 78(4), 576-594. https://doi.org/10.33225/pec/20.78.576

Kemendikbud. (2017). Modul Penyusunan Soal Higher Order Thinking Skill (HOTS). Jakarta: Direktorat Pembinaan SMA Ditjen Pendidikan Dasar dan Menengah.

Kuswana, W. S. (2011). Taksonomi Berpikir. Bandung: Rosdakarya.

Lestari, D. (2016). Pengembangan Soal Tes Berbasis HOTS Pada Model Pembelajaran Latihan Penelitian di Sekolah Dasar. Journal Universitas Pendidikan Indonesia.

Malik, A., \& Chusni, M. M. (2018). Pengantar Statistika Pendidikan. International 
Journal of Physiology.

Naga, D. S. (2002). Pengantar Teori Skor pada Pengukuran Pendidikan. Jakarta: Gunadarma.

OECD. (2019). "PISA 2018 Mathematics Framework", in PISA 2018 Assessment and Analytical Framework,. OECD.

Putri, Resty A and Rosliyah, Y. (2020). Analisis Distraktor Butir Soal Bunpou Shokyuu Kouhan Semester 2 Tahun 2018/2019 Prodi Pendidikan Bahasa Jepang Unnes. Kiryoku, 4, 20-28.

Reniasih, G. N. (2020). Penerapan Bimbingan Berkelanjutan untuk Meningkatkan Kemampuan Melaksanakan Asesmen Autentik pada Guru di SD. Jurnal Ilmiah Sekolah Dasar, 4(1), 41. https://doi.org/10.23887/jisd.v4i1.24278

Rintayati, P., Lukitasari, H., \& Syawaludin, A. (2020). Development of Two-Tier Multiple Choice Test to Assess Indonesian Elementary Students' Higher-Order Thinking Skills. International Journal of Instruction, 14(1), 555-566. https://doi.org/10.29333/IJI.2021.14133A

Sari, A. I. C., \& Herawati, M. (2014). Aplikasi ANATES Versi 4 dalam Menganalisis Butir Soal. Faktor Jurnal Ilmiah Kependidikan, 1(2), 203-214.

Setiawaty. (2017). Indeks Tingkat Kesulitan (ITK) Dan Keberfungsian Distraktor Soal Pilihan Ganda UAS Genap Mata Pelajaran Bahasa Indonesia. SEMNASBAHTERA, 68-78.

Sugiyono. (2007). Metode Penelitian Pendidikan Pendekatan Kuantitatif, Kualitatif, dan R\&D. Bandung: Alfabeta. Journal of Chemical Information and Modeling.

Wicaksono, V. D. (2018). Pengembangan Perangkat Asesmen Autentik Pada Tema Makanan Sehat Dan Bergizi Kelas Iv Sekolah Dasar. Inventa, 2(2), 55-62. https://doi.org/10.36456/inventa.2.2.a1650

Wilson, V. (2000). Education forum on teaching thinking skills. Edinburgh Report, the scottish council for research in education. 